\title{
A new Miocene sirenian from Kutch, India
}

J.G.M. Thewissen and Sunil Bajpai

Acta Palaeontologica Polonica 54 (1), 2009: 7-13 doi:http://dx.doi.org/10.4202/app.2009.0102

We report a new Miocene sirenian from District Kutch, State of Gujarat, India: Domingia sodhae gen. et sp. nov. The new species is a dugongine dugongid with flattened tusk-like upper incisors. Like some other Miocene dugongids, Domningia is large and has complex, bilophodont molars and three-rooted premolars, which are strongly worn. The rostrum is downturned significantly, similar to modern dugongs, and indicative of a specialized feeding mode. Phylogenetically, it is closely related to Dioplotherium, Rytiodus, Corystosiren , and Bharatisiren. Among these, Domningia is most similar to Bharatisiren indica and Dioplotherium manigaulti, in that all three taxa retain multi-rooted premolars. Similar to Bharatisiren, the nasal process of the premaxilla is long. Bharatisiren and Domningia are part of a late Oligocene and early Miocene radiation of dugongines in South Asia.

Key words: Mammalia, Sirenia, Miocene, India.

J.G.M. Thewissen [thewisse@ neoucom.edu], Department of Anatomy and Neurobiology, Northeastern Ohio Universities College of Medicine, 4209 State Route 44, P.O. Box 95 Rootstown, Ohio 44272, USA; Sunil Bajpai [sunifes@iitr.ernet.in], Department of Earth Sciences, Indian Institute of Technology, Roorkee, 247667 Uttarakhand, India.

This is an open-access article distributed under the terms of the Creative Commons Attribution License (for details please see creativecommons.org), which permits unrestricted use, distribution, and reproduction in any medium, provided the original author and source are credited. 